\title{
Ethiopia and Eritrea: A New Relationship Based upon Treaty Obligations, International Law and Mutual Trust
}

\author{
Don Picard, Picard Kentz \& Rowe LLP, Washington D.C. USA, \\ bdpicard@gmail.com \\ Zeray Yihdego, University of Aberdeen, Aberdeen, Scotland, UK, email: \\ Zeray.yihdego@abdn.ac.uk
}

\section{Abstract}

The article revisits the 2000 Algiers Agreements between Ethiopia and Eritrea, including the claims and boundary arbitral decisions issued thereunder, in light of the 2018 Asmara and Jeddah agreements. Similar state practice and relevant international law as well as the geopolitical context are also considered. It is argued that accountability and boundary demarcation issues remain serious challenges in the relations between the two countries; however, it finds that the 2018 Agreements indicate that the parties intend to start afresh in their relations. In particular, the article challenges the misperception that the 'virtual' demarcation decision should be implemented without qualifications; doing so ignores relevant subsequent practice of the parties, the wishes of their border communities and other relevant international law, and therefore could be detrimental to the friendly and peaceful co-existence of the parties. After all, the border issue was not the primary basis for the devastating armed conflict and subsequent no-peace-no-war situation; moreover, other peremptory norms were breached that without question are higher in legal status than the question of compliance with an arbitral award flawed in many respects. It is proposed that a broader, institutionalized and agreed socio-economic, development and integration process pursuant to the 2018 undertakings be given priority to bring lasting peace and prosperity for both countries and the region.

\section{Introduction}

In July and September, 2018 Eritrea and Ethiopia declared their intention to build a new relationship of friendship and comprehensive cooperation, reiterating their commitment to the principles and purposes of the Charter of the United Nations. The commitments set out in the 2018 agreements represent a sharp departure from the parties' relationship of the past 30 years and a change that will benefit not only the two parties. The Horn of Africa/Red Sea region and international peace and security more generally will benefit from constructive and friendly relations between Ethiopia and Eritrea.

This article reviews the two Agreements of 2018 and relevant elements of the Algiers Agreements of 2000 from the perspective of general international law. The Issues of accountability for the armed conflict of 1998-2000 and the obligation to delimit and demarcate the common boundary are 
emphasized. The article concludes that the 2018 Agreements free the parties to start afresh to implement the obligations therein. Hopefully, this will be accomplished through a transparent and institutionalized process based upon mutual interests and international law. Several specific recommendations are offered based upon the experience of other states and international organizations that could facilitate the way forward. To that effect, Section 2 looks into the new initiatives undertaken in 2018 with the purpose of articulating the challenges and priorities of the parties. Sections 3 and 4 then address the two key challenges, accountability and border delimitation/demarcation respectively, the focus being the latter; while the third section articulates relevant preemptory norms of international law the fourth one explores the legal and factual complexities of the boundary decision in accordance with applicable international law, subsequent practice and other relevant cases dealt with by, inter alia, the International Court of Justice. This is followed by Section 5 which sets out an approach for implementation of the 2018 Agreements that can best rebuild the trust and cooperation between the parties needed to accomplish the commitments therein. And Section 6 brings the article to an end by making some concluding remarks.

2. A New Initiative for Friendly Relations: Joint Declaration and Agreement on Peace, Friendship and Comprehensive Cooperation, 2018

\subsection{The Principal Obligations Undertaken}

The "Joint Declaration of Peace and Friendship between Eritrea and Ethiopia" (Joint Declaration) signed July 9, 2018 explicitly turned away from the hostile relationship of May 1998- June 2018, which it described as a "state of war". It went on to acknowledge that these past decades had been a "... very costly chapter, which also had a detrimental role in the Horn of Africa..." and decided "... to make up for lost opportunities...".

The five articles of the Joint Declaration set out a reasonable though ambitious program of agreed actions. These are: establish "intimate" economic, social, cultural and security cooperation; resume transport, trade and communication links and diplomatic relations; implement the "decision on the boundary"; work jointly for regional peace, development and cooperation. These action items were followed by a gracious expression of thanks to "all friends of Eritrea and Ethiopia," and a call for their redoubled solidarity and support.

It is important and realistic that the Joint Declaration provides no explicit timetable or priority among the action items set out; although, the numerical order of their listing may imply a recognition that success in achieving the first three items: peace, comprehensive bilateral cooperation, and resumption of bilateral economic and diplomatic relations, would build the mutual trust necessary for cooperative action on the boundary and joint diplomatic activity within the region. It is also notable that the Joint Declaration is explicitly reaffirmed in the somewhat more extensive "Agreement on Peace, Friendship

\footnotetext{
1 See http://www.shabait.com/news/local-news/26639-joint -declaration-of-peace-and-friendshipbetween-eritrea-and-ethiopia, Preamble (accessed 12 January 2020). See also Desta (2019) 261
} 
and Comprehensive Cooperation Between the Federal Democratic Republic of Ethiopia and the State of Eritrea" (Comprehensive Agreement) signed in Jeddah, Saudi Arabia on September 16, 2018. ${ }^{2}$

The Comprehensive Agreement adds several important substantive and procedural obligations to those set out in the Joint Declaration. The Substantive obligations are: respect for each other's independence, sovereignty and territorial integrity; commitment to the principles and purposes of the United Nations Charter; develop Joint Investment Projects and Joint Special Economic Zones; promote global peace, security and cooperation; and combat terrorism, as well as trafficking in arms, drugs and people, according to international conventions. A practical procedural element of the Comprehensive Agreement provides for establishment of a High-Level Joint Committee and Subcommittees to oversee implementation of the Agreement. ${ }^{3}$ Despite the fact that both treaties do not have formal provisions relative to ratification and entry into force and have not yet been deposited with the United Nations or approved by their respective legislative bodies, they are signed by the heads of State/Government of the two countries, and therefore bind the parties under international law ${ }^{4}$. The signing of the Comprehensive Agreement was also observed by the UN Secretary General.

\subsection{Object and Purpose}

The Object and Purpose of the Joint Declaration and the Comprehensive agreement ("the 2018 Agreements") are quite apparent: to establish peace, friendship and comprehensive economic cooperation in their bilateral relations and to cooperate diplomatically with respect to their economic and security relationships with the international community. All of these obligations are to be undertaken in accord with the principles and purposes of the UN Charter. ${ }^{5}$ The clarity of expression and the compelling need for these objectives cannot be faulted. There is a considerable distance between the past bilateral relationship and the new relationship envisioned; however, the very practical obligations for action set out in the 2018 Agreements are well suited to make progress toward the agreed object and Purpose.

Both parties and the international community will have in mind the failed efforts from 1992 to 1998 to build a cooperative relationship as well as the causes for these failures noted by commentators. These include, a failure to institutionalize bilateral relations, instead relying too much upon the personal relationships between former TPLF and EPLF leaders. ${ }^{6}$ The Comprehensive Agreement speaks directly to this issue by providing for a Joint High-Level Committee and establishment of required Subcommittees. These subcommittees will certainly be needed to deal with each of the

\footnotetext{
2 See http://www.shabait.com/news/local-news/27076-agreement-on-peace-friendship-andcomprehensive-cooperation-between-the-federal-democratic-republic-of-ethiopia-and-the-state-of-eritrea. (accessed 12 January 2020).

3 See Comprehensive Agreement (2018), Articles One - Seven.

${ }^{4}$ VCLT (1969) Art 7 (2) (a).

${ }^{5}$ Comprehensive Agreement (2018), Preamble.

${ }^{6}$ Khadiagala (1999), p. 41; Atinafu and Bayeh (2015), p. 1.
} 
separate and complicated activities set out in Articles Two through Six of the Comprehensive Agreement.

The parties also recognize that the responsibility for accomplishing the objectives set out rests directly upon their shoulders. More than one commentator has noted the outsized role of international actors in drafting and trying to implement provisions of the Agreement on Cessation of Hostilities and the Peace Agreement of June 19, 2000 and December 12, 2000 respectively ("Algiers Agreements"). Clearly the 2018 Agreements must succeed or fail based upon the efforts of the two parties. Nevertheless, the parties are wise to recognize the importance of their new relationship to regional and international security and cooperation, as do in Articles Five and Six of the Comprehensive Agreement and the concluding sentence of the Joint Declaration.

\subsection{Priorities}

As noted above, the 2018 Agreements set no timetable or priorities for accomplishment of the extensive agenda of actions set out there. The parties are, therefore, at liberty to make rational decisions regarding timing and priority as the Joint High-Level Committee and Subcommittees make plans for implementing the actions committed to. Both international and local commentators have recognized the difficulties the parties face and the complexity of resetting bilateral relations. ${ }^{8}$ Not only must the internal political and economic realities of each party be considered, but also the geopolitical rivalries in the Red Sea region must be taken into account. ${ }^{9}$ A review of the relevant literature suggests the following priorities.

First, preserve the peace. International experience has shown that post-conflict peace processes are fragile. ${ }^{10}$ Second, mutual recognition of the sovereignty and territorial integrity of the two states parties must be beyond question. Twenty-seven years after Ethiopia's recognition of Eritrean sovereignty and independence following the 1992 referendum, there should be no question of this; however, Ethiopia should take care to recognize that this remains a sensitive issue for Eritrea. Third, to build trust and confidence it will be essential to quickly initiate practical joint investments and joint special economic zones that have mutually beneficial impact on Eritrean and Ethiopian local populations before taking up more divisive issues.

\subsection{Major Challenges}

\footnotetext{
${ }^{7}$ Kadiagala (1999) pp. 43,52.

${ }^{8}$ Gilkes, Patrick (2005), p250; Maru (2019) pp.14-16.

${ }^{9}$ Woldemariam, pp. 185-187.

10 See e.g. Del Castillo (2008), pp.40-47, 303-309; Fixdal (2012) pp.251-256.
} 
There are two major challenges confronting the parties' implementation of the 2018 Agreements that must be handled with the greatest sensitivity and spirit of cooperation. These are: accountability for the $1998-2000$ war and location and function of the international boundary.

\section{Accountability}

The Eritrea-Ethiopia Claims Commission (“Claims Commission”) ruled that Eritrea violated Article 2 (4) of the Charter in its attack on Ethiopia in 1998 and rejected Eritrea's self-defense and other defenses to Ethiopia's claim. In working to rebuild friendly and cooperative relations, Eritrea should have in mind its responsibility for the extensive injury caused to citizens of Ethiopia by the war, including the resulting hostility towards Eritrea among many citizens of Ethiopia affected by the war, especially those living in the border regions. While both parties have agreed to "close this very costly chapter" of their history, both must be careful to avoid reopening old wounds by their words or actions.

\section{Boundary Location}

In the Joint Declaration and Comprehensive Agreement, Ethiopia has recognized the importance to Eritrea of establishing a final and binding delimitation and demarcation of their boundary. Eritrea should recognize the overriding importance to friendly relations of establishing a boundary that both states can fully support. Eritrea's decision to impose its view of the boundary by force or other interests in 1998 caused a terrible war. This, in addition to Eritrea's military takeover of the Temporary Security Zone beginning in 2004 and refusal of bilateral talks, made Ethiopian acceptance of the Boundary Commission's "virtual demarcation" legally and politically impossible. These two challenging issues will be considered in turn, below.

\section{Accountability issues}

\subsection{Context for Accountability}

The Algiers Agreements comprise the Agreement on the Cessation of Hostilities 18 June 2000 June Agreement) and the Comprehensive Peace Agreement 12 December 2000 (December Agreement [DA]); the latter included the Framework Agreement recommendations (FAR) and the Modalities for Implementation $(\mathrm{MI})^{11}$ of the agreements. These aimed for considerably more than ending the international armed conflict. From the first Framework Agreement proposal prepared by the AU in 1998 there was recognition that several longer-term issues must be addressed in order to normalize relations between Ethiopia and Eritrea and provide for a sustainable peace. These were: 1. Prohibition of the threat or use of force and mandate peaceful settlement of disputes; 2. Accountability for the war and its consequences; 3. Determination of the boundary location; 4. Address the humanitarian consequences of the war, including the impact on communities in the border regions most affected by the conflict and impact on those nationals of the opposing states expelled from their state of residence to the state of their nationality. As will be seen, none of these objectives was fully

${ }^{11}$ Yearbook of the United Nations (2006), volume 60. United Nations: New York. pp 315-17 
accomplished, though some progress was made. This section addresses these issues excluding the third item as it is subject to a detailed treatment separately (Sec 4).

With respect to the first issue, the prohibition of the threat or use of force was only partially addressed. Despite the end of the full-fledged war in the year 2000 Eritrea again threatened to use force against Ethiopia beginning early in 2003; however, there has been no major armed conflict between the parties. Unfortunately, bilateral disputes were not peacefully resolved. Diplomatic relations were suspended and relations were strained until 2018. This cannot be fully explained in isolation. Eritrea's relations with other neighbors were also inconsistent with international norms and the Charter of the UN. For example, in June 2008 Djibouti asserted that Eritrean armed forces had entered Djibouti territory and prepared military instillations there. The UN Security Council issued a statement condemning Eritrea's action. ${ }^{12}$ On December 23, 2009, the Security Council passed resolution 1907 imposing sanctions on Eritrea in response to the country's alleged support for extremist Al-Shabaab militias in Somalia and its refusal to cooperate with Djibouti to find a solution to the border conflict and to withdraw troops from the contested areas. ${ }^{13}$

The fourth issue, related to the humanitarian consequences of the war, was addressed initially by the $\mathrm{UN}^{14}$ and international humanitarian agencies and later, in part, by the Claims Commission. Unfortunately, the hostile relationship between the parties from 1998 until 2018 has prevented many cooperative measures that might have been more effective than individual measures by each state.

\subsection{Accountability for Damages Related to the Conflict}

The Algiers agreements oblige the two Parties, inter alia, to address the negative socio-economic impact of the crisis on the civilian population (FAR8; DA5.1). They further oblige the Parties to establish a neutral claims commission to decide all claims of each party for loss, damage or injury caused by violations of international law by the other party related to the armed conflict (DA5.1).

From the earliest stage of peace negotiations, Ethiopia emphasized the priority of its entitlement to reparations for war damages. Ethiopia's position was that all of its damages were attributable to Eritrea's unprovoked initiation of hostilities. ${ }^{15}$ Indeed, Ethiopia considered it had made a substantial

12 See United Nations, Security Council, 5908th Meeting, S/PV.5908 (12 June 2008), available from https://undocs.org/en/S/PV.5908, p. 2. (accessed 15 December, 2019).

13 See United Nations, Security Council, Resolution 1907, S/Res/1907 (23 Dec 2009), available from https://www.securitycouncilreport.org/un-documents/document/erit-djibou-s-res-1907.php (accessed 5 December, 2019).

${ }^{14}$ See at https://peacekeeping.un.org/en/mission/past/unmee/background.html (accessed 15 December 2019).

${ }^{15}$ See e.g. Eritrea-Ethiopia Claims Commission, Partial Award - Economic Loss Throughout Ethiopia Ethiopia's Claim 7, Part I; Partial Award Jus Ad Bellum claims, (2005) para 7. 
concession in the Algiers Agreements to agree to a claims commission that would assess the losses of both states, even though Eritrea had started the war.

The Claims Commission had by far the most challenging task of the two arbitral tribunals. The war had resulted in some 100,000 deaths and extensive damage to public and private property. The Claims Commission was fortunate in being less in the spotlight of press and political attention than the Boundary Commission, and went about its task carefully and deliberately. The Commission began its work in March 2001 and continued through August 2009. It held 8 hearings with the parties at the Peace Palace in the Hague, some continuing as long as 10 days, where witnesses were examined and the parties' arguments heard. The parties filed thousands of pages of pleadings including evidence, legal analysis and argument. The Commission issued 8 decisions on such matters as the scope of its jurisdiction; the categories of claims to be filed; types of remedies; evidence; and instructions as to how certain claims should be composed. It rendered 17 awards determining liability and damages on the claims filed. Both parties accepted the Claims Commission's decisions. The dollar amount of damages assessed against Eritrea exceeded the amount assessed against Ethiopia. Although damages amounts have not yet been paid, a highly valuable archive of facts and legal analysis was produced for the benefit of the parties as they now begin to work to rebuild normal state to state relations. In addition, the development of the international law of state-to-state claims has been significantly advanced. This work is well analyzed and summarized elsewhere in this volume ${ }^{16}$ and more extensively in Litigating war: Arbitration of Civil Injury by the Eritrea-Ethiopia Claims Commission ${ }^{17}$. However, some of the jus in bello and jus ad bellum violations are re-visited below due to their importance and

relevance to the overall implementation of the 2018 agreements, the much-needed confidence building between the parties and to correcting the incomplete narrative of compliance or non-compliance with the Algiers Agreements and subsequent decisions.

\subsubsection{Violation of Jus ad Bellum: a Peremptory Norm of International Law}

Ethiopia pleaded before the claims Commission that Eritrea invaded it starting from Badme which subsequently spread to other parts of the border ${ }^{18}$. Eritrea challenged Ethiopia's view by asserting that its use of force was in response to the occupation of its territories by Ethiopia ${ }^{19}$. The Claims Commission concluded that

Eritrea violated Article 2, paragraph 4, of the Charter of the united Nations by resorting to armed force to attack and occupy Badme, then under peaceful administration by Ethiopia, as well as other territory in the

\footnotetext{
16 Snider et al (2019) 11-34

${ }^{17}$ Murphy et al (2013)

18 Ibid, 108-119

${ }^{19}$ Murphy et al (2013) 119-20
} 
Tahtay Adiabo and Laelay Adiabo Woredas of Ethiopia, in an attack that began on May 12, 1988, and is liable to compensate Ethiopia, for the damages caused by that violation of international law ${ }^{20}$.

While Gray ${ }^{21}$ criticized this bold ruling on grounds of jurisdiction and the Commission's lack of expertise in the subject, Weeramantry ${ }^{22}$ found it a factually and legally justified ruling. As cogently explained by Yiallourides and Yihdego in the 2019 volume of this Yearbook', a state has no legal right to seize territory under peaceful administration of another state based upon a state's own view of its legal entitlement. To the contrary, it is the status quo that is protected, for the reasons and legal authorities clearly set out there, ${ }^{23}$ which reaffirms the validly of the jus ad bellum decision of the Commission.

As mentioned earlier, the Commission awarded financial compensation based upon, or in connection with, the jus ad bellum claims, but it has never been paid ${ }^{24}$. Yet the use of force by Eritrea in 1998 through 2000 in violation of the UN Charter gave rise to other legal interests and obligations by virtue of constituting a violation of a peremptory norm of international law. Violations of peremptory norms are not solely violations vis a vis the direct victim but also offenses against the international community in general ${ }^{25}$. Among the consequences of Eritrea's use of force would be the requirement of nonrecognition of the consequences of the illegal act by other subjects of international law and giving assurances of non-repetition by the perpetrator ${ }^{26}$. Some indication of the international community's appreciation of the non-recognition obligation would be the early involvement of the US, the AU, the EU and other states in seeking to end the armed conflict of 1998-2000. From the first intervention by international parties seeking resolution of the armed conflict, the requirement that Eritrea return its armed forces to the positions they held before May 6, 1998 was included. ${ }^{27}$ Notably, there has been no 'assurances and guarantees of non-repetition' given by Eritrea to date. Indeed, as described below, beginning in 2003 Eritrea threatened the use of force again.

As a theoretical matter it is notable that violation of a peremptory norm may not be waived, either by the victim or other states, by treaty or otherwise. ${ }^{28}$ What is the implication of this principle for the boundary provisions of the Algiers Agreements? This question is beyond the scope of this article but may be relevant to restoration of friendly relations pursuant to the 2018 Agreements. It is notable

${ }^{20}$ Ethiopian Jus Ad bellum Claims, Partial Award (2004), para 16

${ }^{21}$ Gray (2006) 699-721.

22 Weeramantry (2006) 45.

${ }^{23}$ Yiallourides \& Yihdego (2019) 35-62, 50-57

${ }^{24}$ Snider et all (2019); see also Murphy et all (2013) 127-151

${ }^{25}$ United Nations. International Law Commission et al. 2002, 276

${ }^{26}$ Crawford (2019), 598-599.

${ }^{27}$ Framework Agreement, Recommendation 3; see also ILC, 'Third report on peremptory norms of general international law (jus cogens) by Dire Tladi', Special Rapporteur, 12 February 2018, A/CN.4/714, para 86 at https://undocs.org/pdf?symbol=en/A/CN.4/714 (accessed 29 January, 2020)

28 VCLT Articles 53, 71. 
that Eritrea has never acknowledged its obligations arising from initiating the armed conflict in 1998. Indeed, rather than expressing concern for the detrimental impact on Ethiopia and the international community as a whole, Eritrea has generally represented itself as having been the victim, because Ethiopia refused to accept a "virtual" demarcation and because the international community has not imposed that demarcation by force.

\subsection{2. jus in bello violations}

The Claims Commission had also dealt extensively with jus in bello accountability issues. Both Parties were held responsible for various violations, although to varying degrees. Ethiopia was held responsible, inter alia, for not paying compensation for Eritrean-owned-trucks and buses that were taken by Ethiopia during the armed conflict, failure to prevent serious violations such as rape by its soldiers, looting and displacing civilians, attacking a reservoir in Asab considered to be indispensable to the civilian population and an indiscriminate aerial bombardment in Asmara ${ }^{29}$.

In contrast, the Commission found, in addition to the jus ad bellum violation, that Eritrean military forces and occupying authorities committed many offences against civilians, including: physical abuse of civilians by means of intentional killings, beatings, and abductions; widespread looting and property destruction; wounds caused by small arms fire; looting and stripping of Zlambessa town; deliberate, unlawful destruction of $75 \%$ of the structures in Zalembessa town; excessive violence by Eritrean soldiers against civilians including frequent beatings and intentional killings; failing to prevent rape of women by its soldiers; failing to release civilians taken into custody or provide information regarding them; failing to prevent its military aircraft from dropping cluster bombs in the vicinity of a school and its civilian neighborhood in the town of Mekele; and abduction, forced labor and conscription of civilians $^{30}$.

Although any of the above violations by both sides are abhorrent irrespective of who did them and the nationality of the victims, the intentional and widespread attacks by Eritrea, including deliberate targeting of Ethiopian civilians and civilian targets constitute grave breaches ${ }^{31}$ of international humanitarian law; such breaches of the fundamentals of jus in bello amount to a violation of preemptory norms of international law. ${ }^{32}$ The Commission awarded compensation for both the parties for such violations, but so far neither party has made the payments awarded.

The key questions which follow from such serious violations of international law by the parties, including jus cogens norms, that led to awarding compensation by the Commission include: would the decisions on jus ad bellum and jus in bello be implemented as part of the Algiers and Jeddah agreements?

\footnotetext{
${ }^{29}$ See e.g. Partial Award - Western Front, Aerial Bombardment and Related Claims - Eritrea's Claims, pp4446.

${ }^{30}$ See e.g. Partial Award Central Front Ethiopia's Claim 2, pp30-31; Partial Award Western and Eastern Fronts Ethiopia's Claims 1 \& 3, pp. 22-23

31 Protocol Additional to the Geneva Conventions of 12 August 1949, and relating to the Protection of Victims of International Armed Conflicts (Protocol I), 8 June 1977. Art 85.

32 Meron (1987) 350.
} 
If the answer to this is to the affirmative, the accountability question must be fully addressed including the consequences of responsibility under international law. If the answer is to the negative, the Parties may opt to close such a dark chapter and begin a new one, without resorting to invoking such accountability issues, but without officially/formally waiving their rights and/or obligations related to the aforementioned preemptory norms.

In short, the accountability challenge concerns some of the most fundamental norms of international law that cannot be ignored. It appears that the 2018 agreements represent the Parties mutual decision to focus on the future rather than the past. Such a mutual decision by the two Parties to the Algiers Agreements is definitive in international law.

\section{Boundary Delimitation and Demarcation}

Ethiopia rejected the Boundary Commission's declaration in 2007 of a "virtual demarcation". Ethiopia believed its position was legally justified for three reasons. First, the Boundary Commission's Delimitation Decision of April 13, 2002 was rushed, incomplete on its face and contained a number of material errors of fact, yet Eritrea insisted it be fully and unconditionally accepted and implemented via demarcation on the ground. Second, the well-established legal practice of demarcation, which requires careful examination of the real-world physical and human geography on the ground during translation from a delimitation decision based on documentary materials on paper to a set of coordinates and physical markers on the ground, was not followed. Instead, the Boundary Commission performed a so called "virtual demarcation" without undertaking the field work it had initially proposed. Third, the Commission's proposed plans for demarcation activities completely omitted consideration of the serious disruption of long-established communities in the border regions that would result if the delimitation decision were to be mechanically implemented on the ground. Such disruption and displacement of communities, already seriously affected by the war, would pose a clear risk of provoking local hostilities that could reignite the armed conflict. The following sections will describe the difficult tasks confronting the Boundary Commission and the parties as they sought to achieve a final and binding delimitation and demarcation of the boundary pursuant to the terms of the Algiers Agreement. The effort to do this was, in effect, suspended in 2007 based upon inter alia each party's belief that the other had breached material provisions of the Algiers Agreement related to the boundary and the demilitarization of a Temporary Security Zone separating the armed forces of the two sides. ${ }^{33}$

\subsection{Delimitation and Demarcation Process}

The Algiers Agreements provided that a neutral boundary commission composed of 5 members would be established to determine the "borders existing at independence" "... on the basis of

33 See e.g. United Nations, Security Council, Report of the Secretary General on Ethiopia and Eritrea, paragraph 3 (Eritrean fortifications, tanks and artillery in the Temporary Security Zone constitute direct violations of the Algiers Agreements) ,paragraph 14 (Ethiopian Foreign Minister letter to Eritrea stated Eritrea had committed a material breach of the Algiers Agreements) S/2007/645. 
pertinent colonial treaties and applicable international law". The commission was to delimit and demarcate these borders. The terms "delimit" and "demarcate" are terms of art in the law of territorial and boundary entitlement. Delimit refers to a description or definition of a boundary, generally in some form of writing, which might include maps or coordinates. Demarcate refers to a procedure of demarcation, i.e. the marking, literally, of the frontier on the ground by means of posts, stone pillars, and the like. It is not uncommon that boundaries of states may be delimited in various ways and yet remain undemarcated, either because of a dispute or because no need has arisen for physical markers. ${ }^{34}$ Although the Algiers Agreements did not define these terms, the fact that both terms were used indicated that both a definition phase and a phase for marking of that definition on the ground would be required.

Article 4 of the December 2000 Agreement, paragraphs 12, 13 and 14 makes clear that the establishment of a border was to be accomplished in two phases and set out the parameters of the Commission's and the parties' activities. The Boundary Commission is directed to meet within 15 days after it is constituted and endeavor to make its decision concerning delimitation of the border within 6 months of its first meeting. The Commission was given the discretion to extend this deadline. Upon reaching a final decision regarding delimitation of the border the Commission is to transmit its decision to the parties and the Secretaries General of the AU and the UN for publication and then arrange for expeditious demarcation. Unless a valid demarcation was concluded there could not be a final and binding boundary in accord with the terms of the Algiers Agreements.

All five Boundary Commissioners were finally appointed by June 12, 2001. Parties were required to file memorials by June 30, 2001 and counter memorials by 22 September, 2001. Replies were filed on 29 October and oral argument was held in the Hague from 10 through 21 December 2001. The Commission issued its Decision Regarding Delimitation of the Border ("Delimitation Decision") 35 on April 13, 2002. The Commission's decision to move so quickly was likely the result of considerable international pressure and public attention. The international community was concerned that fighting could breakout again. In retrospect the rapid process of pleading, hearing, and issuance of the delimitation decision may have been responsible for the numerous factual errors and inconsistences between the Delimitation Decision's description of the boundary in its text and its location of a boundary line on the maps provided with that text. The Commission had planned to visit the boundary regions as part of its delimitation work, however, for reasons not fully explained to the parties these visits did not take place. Apparently, this was one reason the Delimitation Decision deferred a number of delimitation issues to the demarcation phase, as discussed below.

${ }^{34}$ Crawford (2019), 212-213.

35 Eritrea-Ethiopia Boundary Commission. (13 April 2002) "Eritrea-Ethiopia Boundary Commission Decision Regarding Delimitation of the Border between The State of Eritrea and The Federal Democratic Republic of Ethiopia," available from https://legal.un.org/riaa/cases/vol_XXV/83-229.pdf, paras 1.15-1.19 (accessed 25 December, 2019). 


\subsection{Challenging task}

The Boundary Commission faced a very difficult task. Accurate identification of the boundary according to international law and colonial treaties would require exacting work by the Commission and pose a considerable challenge to the two parties who would be required to prove the practice of the parties as to administration of territory and provide their respective analyses of the text of a number of relevant treaties dating back to the 1880s dealing with various different segments of the boundary. As the Boundary Commission explained in its Delimitation Decision, international law places considerable weight on the subsequent practice of the parties to a boundary treaty, not only for interpretation of any relevant treaty texts, but also as an independent method of establishing title to disputed territory. It is quite possible that conduct or practice may affect the legal relations of the parties such that the application of a given treaty provision may be varied, or may even cease to control the situation. ${ }^{36}$

Also complicating the Commission's work was the fact that there were numerous, relevant colonial treaties, the earliest in 1889 and the last in 1908. In many cases the locations specified in the treaties were obscure or were difficult or impossible to identify in modern times.

Evidence of the subsequent practice of the parties regarding the precise boundary location was comprised of official correspondence, governmental decrees etc. issued throughout this period and located in various archives in a variety of locations in Europe and Africa. Moreover, the nature of the boundary region's human geography itself was complicated. The boundary region was the home of long-established communities of distinct ethnicities whose territory was well known to the communities themselves but not necessarily defined by written documents. Thus, for example, when a treaty stated that the Irob people's territory would be in Ethiopia it would require field work in the area to determine where the Irob people were located at the relevant time. Unfortunately, the Commission did not appoint experts or make any personal observation of the terrain in question during the delimitation proceedings. Instead, such matters were deferred by the Commission to the demarcation phase and thus, as it turned out, were never considered. Of particular concern to Ethiopia was the situation of the boundary communities, in part because these communities and other residents of the region had borne the greatest burden of war damages as a result of being situated in the midst of the two-year war and Eritrean occupation of Ethiopian territory.

\subsection{Complex Ethnicities and History of Boundary Communities}

The boundary region had long been home to a number of ethnically and culturally distinct and cohesive communities, Tigreans, Saho (including the Irob) and Afar. As the two states presented their boundary positions to the Boundary Commission, the differing ethnicity, culture, and strong cohesiveness of the communities living in the border region should have been fully considered, but it was not. Since the obligations of the parties to the Algiers Agreement included addressing the negative

\footnotetext{
${ }^{36}$ Delimitation Decision, p. 22, para 3.6, 3.8.; See also, Crawford (2019) at pp. 221-223.
} 
socio-economic impact on the civilian population and affording humane treatment of nationals of the other party living in their territory, the boundary region communities and territories deserved special care. This was also an important factor if the parties were to establish a border that would result in sustainable peace between Ethiopia and Eritrea, a central objective of the Algiers Agreements. Ethiopia insisted that this factor be an important focus of the demarcation process, but Eritrea rejected such an approach. The failure of these issues to be considered proved to undermine the viability of the Commission's delimitation and demarcation decisions. A boundary delimitation and demarcation that disregarded the border regions' residents risked sparking local conflicts and widespread displacement that could reignite the armed conflict. Had Eritrea and Ethiopia pursued work on their boundary through examination of this issue through the Joint Boundary Commission established in 1997 these issues could have been considered, including with the participation of representatives of the local communities. Another opportunity for such consideration was the demarcation process that was required by the Algiers Agreements to follow the Boundary Commission's Delimitation Decision of April 13, 2002.

This problem of disruption of local communities was identified by a number of experts soon after the Delimitation Decision was made public in 2002 and has continued to be the subject of more recent comment. ${ }^{37}$ Patrick Gilkes pointed out: "Two years of fighting, a hundred thousand dead, a peace agreement and a Boundary Commission have all failed to settle the problems of the border between Eritrea and Ethiopia, or, more pertinently, deal with the relationships of the peoples who straddle this border: Kunama, Tigrean, Saho and Afar." 38 Gilkes pointed out that the Boundary Commission had given little attention to the issues of "subsequent practice of the parties", focusing instead on "colonial boundaries". ${ }^{99}$ Until the war of 1998 the Ethiopian- Eritrean boundary was generally open to movement of people, families and goods. Since 1935 it had been an internal, administrative boundary, not an international boundary and thus had little practical or political significance for these communities. ${ }^{40}$ Ethiopia assumed that the demarcation phase of the boundary process would address such problems, but Eritrea refused to consider the human geography of the region as one of the key factors for delimitation and demarcation.

\subsection{The Delimitation Decision: Not Final; Deferrals to Secure More Information; Errors of Fact}

\footnotetext{
${ }^{37}$ See e.g. Clapham, Christopher (16 Oct 2003) "Notes on the Ethio-Eritrean Boundary Demarcation," at www.aiga-forum.com/clapham0311; Abbink (2009); Maru, Mehari Taddele (2019) "Beyond Borders and Leaders: Toward Sustainable Peace for Ethiopia and Eritrea on Ethiopia/Eritrea," https://studies.aljazeera.net/en/reports/2019/07/borders-leaders-sustainable-peace-ethiopia-eritrea190707092131678.html (accessed 17 Jan 2020).

${ }^{38}$ Jacquin-Berdal and Plaut (2005), p. 233.

39 Ibid., 234.

${ }^{40}$ Ibid, 232-233.
} 
The April 2002 Decision makes abundantly clear the provisional nature of the line described by its text and illustrative maps. The Decision noted: 1) that the Commission lacked reliable information about the facts on the ground, for example, specifically stating that it was "hampered by the inability of the Parties to identify with sufficient particularity the location of the places to which they refer" ${ }^{\prime 1}$ 2) that there was "no generally agreed map of the area depicting place names with any degree of reliability" 42 and, 3) that "[m]ap evidence [was] not uniform and consistent.... [and] on so small a scale, or so devoid of detail, that it can only be treated as ambiguous in this respect." ${ }^{23}$

The Algiers Agreements consistently recognize the importance of the demarcation stage in the final determination of the border. For example, under Article 14 of the Agreement on Cessation of Hostilities, the OAU and the UN agree to guarantee security arrangements i.e. the TSZ and viability of the UNMEE mission, until "the determination of the common border on the basis of pertinent colonial treaties and applicable international law, through delimitation/demarcation." (emphasis added) Recognizing this, in a joint statement entitled "Securing a Lasting Peace" published on the day of the April 2002 Delimitation Decision, the Secretaries General of the United Nations and the OAU stressed: "The Boundary Commission's decision will only be one step in the resolution of the border conflict. After delimitation ... comes demarcation." ${ }^{44}$

The Commission had not been able to conduct any ground examination prior to the issuance of the April 2002 Delimitation Decision. In consequence, the April 2002 Decision stated that the coordinates set forth in the Decision were "not necessarily final and the Commission may have to adjust or vary them in the course of demarcation" and that the maps were for illustrative purposes only. ${ }^{45}$ The Decision specifically deferred many important delimitation issues to the demarcation phase and did not provide even provisional coordinates for important sections of the boundary, such as the sections around the towns of Zalambessa, Tserona, and Bure.

There is also in the April 2002 Delimitation Decision a pattern of references to the need for "adjustment" or "variation" of the Treaty alignment in order to maintain manageability and rationality in terms of local conditions. The Delimitation Decision states at paragraph 4.78, for example, that "the boundary line resulting from the 1900 Treaty must be adjusted so as to ensure that Tserona, and the Acran region and Fort Cadorna are placed in Eritrean territory. . . . The boundary resulting from the 1900 Treaty must be further adjusted . . . so as to place Zalambessa in Ethiopian territory." ${ }^{46}$ The

${ }^{41}$ Delimitation Decision (2002) 4.63.

${ }^{42}$ Ibid

43 Ibid, 4.67.

44 United Nations, Ethiopia/Eritrea: Announcement of the EEBC decision, (2002), available from https://search.archives.un.org/uploads/r/united-nations-

archives/7/b/1/7b166a69540e94b69e564520b1d546496d47f669bd63207642159cf9b450b83d/S-1095-003005-00003.pdf. (accessed 22 January 2020).

${ }^{45}$ Delimitation Decision, 2.16.

${ }^{46} \mathrm{Ibid}, 4.78$ 
Decision accepts that it may be necessary to depart from the language of a treaty if it does not produce "a manageable boundary." ${ }^{47}$ Thus in its analysis of the Delimitation Decision Ethiopia had every reason to expect that the Commission's recognition for the need for adjustments and variations and for "a manageable boundary" would be a foundation of the demarcation phase of the Commission's work.

\subsection{Ethiopia Provides Extensive Information to Commission Regarding Problems with the Delimitation Decision Needing Attention During Demarcation Process}

Following the April 2002 delimitation decision, Ethiopia made a careful study of the Commission's maps and the text of the decision so that the Commission-acknowledged deficiencies could be addressed. Ethiopia also examined the situation on the ground to the extent allowed by maintenance of the Temporary Security Zone. The initial results of Ethiopia's study were quickly provided to the Commission and Eritrea in a pleading of May 13, 2002.48

Subsequently, at the invitation of the Boundary Commission, in January 2003 Ethiopia filed additional, detailed factual comments, including maps and aerial photographs demonstrating areas in which refinement of the line described in the delimitation decision would be needed. Ethiopia also presented its January Comments to the witnesses to the Algiers Agreement. ${ }^{49}$

Ethiopia's January Comments alerted the Commission to the need to address mistakes and inconsistencies in the Delimitation Decision. For example, the Delimitation Decision called for an adjustment to the Treaty boundary in order to keep inside Eritrea a place called Fort Cadorna. Ethiopia pointed out in its Comments that this adjustment should not be made because Fort Cadorna was actually a well-known place more than 20 kilometers to the northeast of where the Commission identified it to be..$^{50}$

Ethiopia's January Comments also brought to the Commission's attention the consequences of a demarcation that would mechanically impose the delimitation line onto the ground. For example, Ethiopia demonstrated with maps and photographs that such a demarcation would cut a straight-line, 90-kilometer boundary through several Ethiopian communities that happened to lie in its path, such as Badme and Sembel, dividing thousands of people from the necessities of life. In the case of Sembel, such a boundary would cut through the heart of the village, including quite possibly severing into two

${ }^{47} \mathrm{Ibid}, 6.22$.

48 The Federal Democratic Republic of Ethiopia (13 May 2002) "Request for Interpretation, Correction and Consultation," available from aigaforum.com/ethio1.pdf. (accessed 13 January, 2020).

49 The Federal Democratic Republic of Ethiopia (24 Jan 2003) "Comments Pursuant to the December 2000 Agreement, the Commission's Rules of Procedure, the Commission's Demarcation Directions and Instructions Provided at the Boundary Commission's Meeting on 6 and 7 November 2002."

${ }^{50} \mathrm{Ibid}, 1.69-1.79$ 
pieces the village's only school and only church. ${ }^{51}$ In another example, Ethiopia explained that a mechanical demarcation would cut into five essentially useless pieces the road between the important Ethiopian towns of Zalambessa and Alitena. The severing of this indispensable road, which was carved out of mountainsides at a great expense, would cause serious detriment to the local population, including exacerbating Ethiopia's present food crisis. ${ }^{52}$

In March, the Commission issued to the Parties its "Observations" on its approach to the demarcation phase of the case. The Commission acknowledged that it anticipated "anomalies on the ground" and admitted to some errors in the April 2002 Decision. For example, the Commission conceded, at Paragraph 23, that the location of Fort Cadorna as set forth in the April 2002 Decision and as relied on in producing the delimitation line was incorrect.

At the Commission's invitation, Ethiopia filed Comments in May $2003^{53}$ addressing various aspects of the demarcation process and responding to the Commission's Observations. Ethiopia also presented its May Comments to the witnesses to the Algiers Agreement. Among the issues addressed, Ethiopia's May Comments corrected serious misstatements made by the Commission in its Observations regarding evidence. For example, the Observations stated that Eritrea had provided evidence of Eritrean acts of governmental administration for the town of Badme, while Ethiopia had provided insufficient evidence to that effect. In fact, Eritrea did not provide even a single document showing Eritrean administration of Badme. Instead, Eritrea acknowledged Ethiopia's administration. The record of the proceedings contains some 40 documents provided by Ethiopia showing its governmental administration of the town. Ethiopia had also pointed out that in June and July 1998 a committee of ambassadors from AU member countries, at the direction of the AU Visited the relevant areas and met with both parties to ascertain their positions and related factual information. The report of the ambassadors committee stated that they had determined that Badme was under the administration of Ethiopia before 12 May 1998 when Eritrean forces established control of the area by force..$^{54}$

4.6. General International Law and Practice Applicable to the Boundary Delimitation and Demarcation

It is axiomatic that states which voluntarily subject themselves to international arbitration have the right and responsibility to interpret the resulting awards in good faith in the context of the arbitral agreement establishing the tribunal, in this case the Algiers Agreements. International law also requires a reasoned award. When inconsistencies or errors are found in an arbitral award, not only are modifications allowed, they are generally required. International jurists consider it essential that arbitrators exercise their obligation to make modifications when necessary to ensure that an award is

\footnotetext{
${ }^{51}$ Ibid,1.19-1.42

${ }^{52} \mathrm{Ibid}, 1.143-1.149$

53 The Federal Democratic Republic of Ethiopia (2 May 2003)

54 Ibid
} 
not irrational and is factually correct, because there usually is no appellate procedure that allows for a separate juridical body to review and correct awards. An important treatise on this subject by the eminent legal scholar, Michael Reisman, emphasized the need for such modifications in order to maintain confidence in international arbitration as a legitimate mechanism for peaceful resolution of disputes. ${ }^{55}$

It is not uncommon, particularly with respect to highly political disputes, for one or both states to raise objections to some aspect of an award. With respect to boundary disputes, to cite only three of many examples:

- With regard to the 2002 ICJ case Nigeria v. Cameroon, Nigeria rejected part of the decision that would have cut off thousands of Nigerians in the Bakassi Peninsula from their country. This issue was addressed through negotiations between the parties via mediation by the UN Secretary General. Unfortunately, this resolution involved displacement of local populations which took place in 2008 but resulted in continued local protests and Nigerian government interventions. ${ }^{56}$ The continuing difficulties flowing from this ICJ decision will be addressed later in this article.

- Pursuant to the Rio Protocol, Ecuador and Peru submitted their boundary dispute to international arbitration. The arbitral award was accepted by both parties; however, during the demarcation, when ground examination revealed new geographical factors, Ecuador objected to the handling of a section of the boundary. After skirmishes broke out, a new Santiago Agreement was signed in 1996 whereby the "Guarantors" (United States, Brazil, Argentina and Chile) negotiated a resolution which became final in $1998 .{ }^{57}$

- In 1992, the ICJ issued a decision on a boundary dispute between El Salvador and Honduras. Concerns were raised over the decision, which led the ICJ to establish a special commission to study and propose solutions to human, civil and economic problems arising from the decision. Despite this effort, conflicts continued in the boundary area for five years until a final protocol was signed in 1997. Five years later, in 2002, El Salvador raised new objections to the ICJ decision based on facts unknown in $1997 . .^{58}$

Making accommodations to address humanitarian concerns and other local conditions has long been a standard aspect of boundary demarcation processes. This practice should certainly have been

55 Reisman (1971).

56 Gibril (2003) 633-677; Duruigbo (2018) 25. See section ---below for additional details.

${ }^{57}$ Beth A Simmons, in her research "Territorial Disputes and Their Resolution: The Case of Ecuador and Peru" in PEACEWORKS (United States Institute for Peace 1999), lists 12 other Latin American arbitral awards that have been contested by at least one party (e.g., The Beagle Channel Award (1977)).

58 Ibid. 
applied here where the Algiers Agreements requires generally that humanitarian considerations and prevention of further human suffering be a priority. ${ }^{59}$ There are many examples:

- Without any explicit authorization, the U.N. Iraq-Kuwait Boundary Demarcation Commission made a significant deviation from the delimited boundary line at Khowr Abd Allah to give Iraq navigational access. The Commission justified its adjustment as necessary for stability, peace, and security along the border. ${ }^{60}$

- When drawing the post-WWI border of northern Iraq near Mosal, efforts were made to ensure Mosal was not cut off from its source of irrigation and farming hinterlands. ${ }^{61}$

- The League of Nations demarcation commission placed the boundary between Turkey and Iraq in such a way as to include a road connecting two Turkish cities within Turkey. ${ }^{62}$ When the delimitation line passed through the urban area of Abu Kemal, the League Commission rerouted the delimitation line several kilometers to avoid dividing the city. ${ }^{63}$

- The border of post-Ottoman Iraq and Syria was demarcated so as to allow equitable access to both subsurface water and salt-water marshes used by migratory herds. ${ }^{64}$

- Considerations of access to water were also taken into consideration by the commission demarcating the boundary between British Somaliland and Ethiopia. ${ }^{65}$

\subsection{The Demarcation Proceedings, 2002-2006}

Demarcation in the field by the Commission's technical staff of the long, eastern sector of the boundary proceeded expeditiously, and the locations of physical boundary markers were agreed by both parties in 2003. By the end of 2003, as the Boundary Commission sought to work with the parties on plans for demarcation of the central and western sectors of the boundary there were only a few regions of these boundary sectors regarding which the parties disagreed. Ethiopia proposed that

59 Algiers Agreement (December 2000), Articles 2 \& 3; OAU High Level Delegation, Framework Agreement (1998)

60 United Nations Iraq-Kuwait Boundary Demarcation Commission Press Release (18 March 1993), reprinted in Demarcation of the International Boundary Between the State of Kuwait and the Republic of Iraq by the United Nations 83 (Center for Research and Studies on Kuwait, n.d.).

61 Iraq-Turkey: Treaty between United Kingdom and Iraq and Turkey regarding settlement of Frontier between Turkey and Iraq, together with Notes Exchanged, Angora, June 5, 1926. Great Britain, Treaty Series, No. 18 (1927), Cmd. 2912. Article 1.

62 Ibid.

63 Jones, Stephen B (1945) Boundary-Making: A Handbook for Statesmen, Treaty Editors, and Boundary Commissioners. Johnson Reprint Corp.

${ }^{64}$ Ibid, 36.

65 Ibid, 36. 
all areas not in dispute should be demarcated, leaving more difficult areas for discussion with Eritrea and the Boundary Commission. Eritrea rejected demarcation of agreed areas.

The field work needed for demarcation of the central and western sectors would be more sensitive than the completed work on the lightly populated eastern sector. The central and western sectors were heavily populated including many towns and villages. These areas were also where the most intense fighting had taken place during the war. Some of these areas of Ethiopia had been occupied by Eritrean forces for two years with residents experiencing grave violations of international law, including beatings, killings and abductions of civilians and widespread looting and destruction of civilian property, by the occupying forces. ${ }^{66}$ Though the disputed areas were few, the parties had sharply differing positions regarding them. Eritrea refused to engage in bilateral discussion on these matters with Ethiopia.

\subsection{Eritrea Threatens Use of Force; Challenges Peacekeeping Force}

As the Security Council and UN Secretary General sought to assist the parties and the Commission to peacefully resolve these disagreements, Eritrea began a series of threats to use force if Ethiopia sought changes to the delimitation decision. In a March 11, 2003 letter to the UN Security Council, Eritrea stated that Ethiopia's submissions of comments to the Commission were a "recipe for conflict and war". In November 2003 Eritrea withdrew its ambassador to the AU, lashing out at the AU for failing to take Eritrea's side in the dispute. The recalled Ambassador in an interview stated, "You should appreciate the magnanimity of my government which has exercised maximum restraint and tolerance for a long time." ${ }^{67}$ In a December 14, 2003 interview, Eritrea’s Foreign Minister stated, "We view all of Ethiopia's statements and positions as a declaration of war." ${ }^{\text {, }}$

Ethiopia considered such threats to be violations of the Algiers Agreements' prohibition of the threat or use of force. Soon, Eritrea moved to breach the rules protecting the TSZ and began to block movements of the UNMEE Military Observer Mission required to maintain demilitarization of the TSZ. Since UNMEE patrols were also needed to protect the work in the TSZ of the Commission's technical demarcation staff, the effect of Eritrea's interference with UNMEE also made the physical process of demarcation impossible. These actions also constituted breaches of the terms of the Algiers Agreements.

In his "Report to the Security Council of 19 December, 2003 the Secretary General described the situation as follows:

3. As was the case at the same time in 2002, a number of formations of the Eritrean Defense Forces have been temporarily relocated from Sector Centre to West, ostensibly for agricultural and construction activities.

\footnotetext{
${ }^{66}$ See e.g. Partial Award Western and Eastern Fronts Ethiopia’s Claims 1 \& 3, pp. 22-23.

${ }^{67}$ Interview with recalled AU ambassador Salih Omer, IRIN (21 November 2003).

68 "Eritrean Foreign Minister views Ethiopia's position as a declaration of war", Sudan Tribune (16 December 2003).
} 
UNMEE continues to monitor -to the extent possible-these movements, which have involved larger numbers of troops than previously and, unlike in the past, complete military formations. p.1

35. In addition to an internationally recognized border, a crucial aspect of a well-functioning and mutually beneficial relationship between two neighboring States is an open channel of communication at all levels. While I acknowledge that Eritrea has certain reservations about initiating a dialogue with Ethiopia until the border has been demarcated, it must be stressed that the continued absence of dialogue will make improvement of relations exceedingly difficult and that such dialogue may be the only way to overcome the current impasse before the situation further deteriorates.

37. However, while the international community will strive to assist Eritreans and Ethiopians, ultimately it is for the parties themselves to find the best way to move the process forward and to help their people to overcome the serious economic and humanitarian difficulties which are currently affecting them. p.9.69

\subsection{4-2007: Demarcation Deadlock; International Mediation; Eritrean Army Enters TSZ and Blocks UNMEE}

Beginning in 2004, The international community, the UN Secretary General and friendly states, including the US and the UK, sought to use their good offices to establish state to state communications between the parties. In a letter to the Security Council of 9 February, 2004 the Secretary General informed the Security Council of his appointment of the former Canadian Foreign Minister, Lloyd Axworthy, as his Special Envoy to meet with the parties to move the demarcation process ahead. The Security Council expressed its full support. (S/2004/102; S/2004/103) Ethiopia strongly supported this initiative and senior government official met with Mr. Axworthy in January, but Eritrea refused to see him. An Eritrean spokesman stated, "the concept of a special envoy is not acceptable to us." ${ }^{\prime 70}$ On January 9, 2004 Eritrea's Foreign Minister clearly threatened war stating: "It would also be necessary to convince Ethiopia to withdraw its refusal in order to spare the region a new war." 71

2005 saw no change in the parties' positions, however, Eritrea intensified its violations of the Temporary Security Zone and blocked UNMEE monitoring operations. The Secretary General's report to the Security Council of 22 January 2006 (S/2006/1) described the situation:

2. Since my last report to the Security Council, there has been a serious deterioration of the security and political situation in the UNMEE Mission area, in particular in and around the Temporary Security Zone,

${ }^{69}$ United Nations, Security Council, Progress Report of the Secretary-General on Ethiopia and Eritrea, S/2003/1186 (19 Dec 2003), available from undocs.org/S/2003/1186.

\footnotetext{
70 BBC News (2 Jan 2004) "Eritrea rejects new peace envoy," http://news.bbc.co.uk/2/hi/africa/3362301.stm.

${ }^{71}$ 'Eritrea asks international community to help avoid a "new war" with Ethiopia', AFP (9 January 2004).
} 
which has become increasingly tense and potentially volatile. This situation is a result of an accumulation of unresolved issues, in particular the stalemate in the demarcation process caused by Ethiopia's refusal to fully accept, without preconditions, the decision of the Eritrea-Ethiopia Boundary Commission of 13 April 2002; the forward deployment of Ethiopian troops since December 3004; violations of the Temporary Security Zone; and the increasing restrictions imposed on UNMEE by the Eritrean authorities, including a ban on all helicopter flights by UNMEE within Eritrean airspace. This action by the Government of Eritrea has severely reduced the Mission's capacity to implement its monitoring mandate as requested by the parties in the Agreement on Cessation of Hostilities signed at Algiers on 18 June 2000 and authorized by the Security Council in its resolutions 1312 (2000) of 31 July 2000 and 1320 (2000).

In early 2006 the US Government undertook a new initiative to resolve the demarcation dispute. A conference of the witnesses to the December 2000 Agreement was convened in New York and issued a statement urging the parties to resolve their differences. A senior State Department delegation attended the Boundary Commission meeting with the parties, and senior State Department officials pressed both parties to resolve their differences through negotiation. The Assistant Secretary of State for African Affairs made an official visit to the region in order to meet with the leaders of both states. She was received by the Ethiopian leadership in Addis Ababa but had to cancel a trip to Asmara when the leadership there refused to meet with her.

The Secretary General's Report to the Security Council of 22 January 2007 summarizes the situation on the ground in 2006 as follows:

2. The military situation in the Temporary Security Zone and the adjacent areas has remained tense and volatile, since over 2,000 troops of the Eritrean Defence Forces (EDF), along with tanks, artillery and air defence equipment, began entering the Zone in Sector West and has also extended to Sector Centre.... ${ }^{2}$

Ethiopia considered Eritrea's refusal to discuss its concerns about the boundary delimitation decision, Eritrea's infringement of the temporary security zone and its threats to use force to be material violations of the Algiers Agreements.

The Secretary General's 1 November 2007 Report to the Security Council noted construction of additional defense facilities and a number of new camps of Eritrean Defense Forces, thousands of military personnel, along with tanks and artillery which, he stated, constituted direct violations of the Algiers Agreements. He also noted that Ethiopia had notified Eritrea that these actions were a material breach of the Algiers Agreements. ${ }^{73}$

\subsection{Boundary Commission’s Eccentric Decision}

The Boundary Commission had done an incomplete job as it acknowledged in the Delimitation Decision. The Commission, as reflected in its Delimitation Decision text, anticipated that gaps and

\footnotetext{
${ }^{72}$ Report of the Secretary General to the Security Council of 22 January, 2007 (S/2007/33)

73 United Nations, Security Council, Report of the Secretary General on Ethiopia and Eritrea, S/2007/645, paragraphs $3,4,14$.
} 
incomplete information due to lack of direct Commission examination of the boundary regions on the ground could be remedied during the demarcation process. This was a reasonable expectation and consistent with experience in other situations; however, Ethiopia and Eritrea, each for their own separate reasons, would not cooperate on the various tasks a conventional demarcation required.

Unfortunately, the Boundary Commission, wishing to be finished with what had become an onerous task, made an eccentric and legally questionable decision in 2006. Unable to have its field staff work in the central and western sectors of the boundary due to disagreement between the parties, the Commission could have simply suspended the demarcation process. Instead, the Commission declared its demarcation work on the ground, now blocked by Eritrea's interference with UNMEE security operations, to be unnecessary. It proposed to set out coordinates it considered satisfactory for emplacement of boundary markers in the western and central boundary sectors, even though these locations had not been visited or surveyed by its technical team. The Commission pronounced its coordinates to be a "virtual demarcation". The Commission warned the parties that if they had not both agreed to allow a conventional demarcation by the end of 2007 , the Commission would declare its "virtual demarcation" list of coordinates to be a legally effective demarcation pursuant to the Algiers Agreements and dissolve itself. In the event, this is precisely what occurred in $2007 .{ }^{74}$

\subsection{The Parties' Positions Regarding the Demarcation Phase}

Ethiopia would not accept a "virtual" demarcation. Ethiopia felt that the Commission had not engaged in a demarcation process that respected international practice or the terms of the Algiers Agreements. In Addition, the Algiers Agreements clearly stated that the parties must address "the negative socioeconomic impact of the crisis on the civilian population" and most importantly, prevent renewal of armed conflict. If mistakes and "manifest impracticabilities" (the Boundary Commission's words) remained uncorrected by the demarcation process, local disagreements could escalate into new fighting. Ethiopia believed that the Algiers Agreements required cooperation between the parties, at a minimum a good faith effort to discuss all areas of disagreement without threats of force or other hostile actions inconsistent with the terms of the Algiers Agreements. Since 2001, however, Eritrea had refused to have any state-to-state talks with Ethiopia on the boundary or any other matters. Beginning in 2003 Eritrea repeatedly threatened the use of force to resolve the boundary matter. Ethiopia's efforts to engage with Eritrea, the Boundary Commission and the international community to make sure that deficiencies in the Delimitation Decision were remedied in the demarcation process were denounced by Eritrea. Eritrea's Legal Advisor stated:

It is incumbent upon Ethiopia immediately to express unconditional respect for the work of the BC, including full acceptance of the 13 April 2002 Award [sic].75

Ethiopia considered that Article 4 of the December 2000 Agreement explicitly required a two-phase process, delimitation followed by demarcation, in order for a final and binding boundary to be

\footnotetext{
${ }^{74}$ Boundary Commission Statement (2006) pp. 771-799

${ }^{75}$ Ibid.
} 
established. The Cessation of Hostilities Agreement required that the UN Peacekeeping Mission continue to monitor the Temporary Security Zone and ensure its demilitarization until the demarcation was completed and the boundary established. Intense diplomatic efforts by the international community through 2006 were unable to significantly modify the parties' positions. In effect, the two parties effectively suspended their respective implementation of the Algiers Agreements boundary-related provisions based upon what each party considered to be material breaches of the Algiers Agreements by the other party.

\subsection{Concluding Observations}

In conclusion, this section offers three findings: first, there were serious legal, technical and practical problems with the Demarcation Decision; second, Ethiopia was justified in suspending work on the demarcation process based upon Eritrea's material breach of the Algiers Agreements provisions on preservation of the TSZ and its threat to use force in response to Eritrea's pleadings seeking correction of the Delimitation decision. Finally, it demonstrates the difficulties of implementing the Delimitation Decision without further work and good faith negotiations in the context of similar cases, decisions and practices.

It is remarkable that many commentators and experts, since the breakdown of progress on the boundary after 2003, have been free in their criticism of Ethiopia's refusal to accept the Boundary Commission's "virtual demarcation" without taking account of the factors described in the sections above. These included the risk of massive displacement of border populations upon reallocation of territory. But there were positive elements of the post-war boundary process, also largely ignored by critics. By 2004 some 2/3s or more of the Commission's Demarcation Decision line was agreed between the parties and could have been demarcated then. Eritrea refused to consider this step, which

might have been a useful confidence-building measure, and proceeded to move its military forces into the Temporary Security Zone, a measure which destroyed any prospect of restoring normal bilateral relations. The new Joint High-Level Committee addressing the boundary should have in mind both positive and negative factors.

5. Moving Forward: Don’t Repeat Mistakes of the Past; Make Use of Best Practices Developed in Other African Boundary Contexts

The 2018 agreements look forward to a future that rejects past mistakes. Comprehensive cooperation is to replace conflict and hostility while practical procedures and joint institutions are mandated to implement this vision. Twenty years have passed since the Algiers agreements were concluded. During that time some very constructive practices of transnational economic cooperation and peaceful resolution of disputes, including boundary disputes, have been developed in Africa. In implementing the 2018 agreements, Ethiopia and Eritrea may find such examples of interest. Of course, serious difficulties and conflicts have also arisen or continued in Africa. To conclude this article such positive and negative experience is noted with the hope that it may usefully inform the Parties' efforts to meet the challenges ahead. 


\subsection{The Need for Fresh Beginning on Wider Opportunities}

\subsubsection{Good Faith Interpretation of Treaty Obligations}

Two destructive wars since 1998, one hot and the next cold, have been waged, in part, because Ethiopia and Eritrea could not peacefully resolve differences over the location of their mutual boundary. Against this background, the two states entered into the 2018 Agreements pledging to open a new chapter in bilateral relations founded upon comprehensive cooperation and committed to the principles and purposes of the United Nations Charter. The first of these two Agreements commenced with the mutual recognition of the loss of opportunities over the past decades and the determination to "...close this very costly chapter...". 76 Earlier sections of this article have dealt with the major obstacles facing Ethiopia and Eritrea as they implement the 2018 Agreements: accountability for the 1998-2000 war and delimitation and demarcation of their boundary. A good faith interpretation of "...the ordinary meaning to be given to ... [the 2018 Agreements] ... in their context and in the light of [their] object and purpose ..."77 would be that in implementing the 2018 Agreements the parties should not be burdened by past treaty obligations but be free to assess the current situation in light of their 2018 commitments to achieve comprehensive cooperation, lasting peace and regional and global peace and security. ${ }^{78}$ This reading of the 2018 Agreements leaves considerable latitude to the parties to make arrangements upon which they can agree and which will facilitate development of the friendly relations envisioned. Certainly, there is one point that must be clear from any possible reading of the 2018 Agreements, i.e. a boundary that is not the product of mutual agreement or that must be maintained by force of arms over the objection of either party is excluded, as separately treated further (Sec 5.2).

\subsubsection{Implementing the 2018 Agreements; High Level Joint Committee}

To implement the terms and objectives of the 2018 Agreements the practical institution of a HighLevel Joint Committee and necessary subcommittees was provided for. This bilateral institution may well be the essential linchpin for fulfilling the treaty commitments of 2018. More important than the presence of the distinguished national and international officials gathered in Jeddah on 16 September 2018 to sign and support the 2018 Agreements will be the work of the much larger group of government and community officials and representatives of the two parties needed to carry out the tasks set out in these treaties. The planning and analysis and implementation of the resulting projects for trade and investment and boundary demarcation and management will require the full resources of the two states at local, national and diplomatic levels. This large scale, cooperative effort should not be looked upon as a burden. Instead, it is the best means of building within each state and between them the new relationships and mutual confidence that must be the foundation of new bilateral relations of comprehensive cooperation.

\footnotetext{
${ }^{76}$ Joint Declaration of Peace and Friendship between Eritrea and Ethiopia (2018).

77 VCLT Article 31 (1)-(4). See also Mitchell, et al (2015), 37, 50

${ }^{78}$ Comprehensive Agreement, Preamble.
} 


\subsubsection{Practical Economic, trade, investment, cultural, transport, communication, and social cooperation measures}

Both of the 2018 Agreements list cooperation on the seven issues in the above subtitle before the boundary issue. This rightly indicates that repairing relations commencing with projects likely to be useful and popular for the public should come first. These would engage government, community and cultural organizations at national and local levels early in the implementation process and build wide support for the more difficult security and boundary issues that would be taken up next. The biggest economic and security gains will come when bilateral relations reach a point of mutual trust and confidence such that both parties can substantially reduce the huge costs of arms purchases and the size of their military forces, but these gains will only follow whatever time is needed to rebuild friendly relations in the other areas included in the 2018 Agreements.

\subsubsection{Joint Investment Projects; Joint Special Economic Zones}

The 2018 Agreements refer to Joint investment projects and Joint Special Economic Zones. In planning for special economic zones and joint investments it would seem appropriate for the Joint High-Level Committee and relevant subcommittees, including those addressing boundary issues, to focus on the particular needs of those regions and communities most adversely affected by the war on both sides of the boundary. Indeed, doing so is required by the parties' legal obligations arising from human rights, humanitarian and state responsibility law as to those populations most affected by the war and Eritrea's obligations resulting from the violation of the jus ad bellum. Legal rights would also accrue to communities affected by any dislocation resulting from final boundary adjustments.

\subsection{A Judicious Approach to Boundary Delimitation and Demarcation}

\subsubsection{Boundary Management, Delimitation and Demarcation}

Considerable experience with boundary management, delimitation and demarcation has been developed by African states, regional organizations and the African Union since the continent's decolonization. There remain quite a number of territorial and boundary disputes today. ${ }^{79}$ Past and present disputes have been intensively studied and reported on by journalists, scholars and experts during the past three decades and before. ${ }^{80}$ The African Union began consideration of establishment

79 See e,g. Africa's International borders as potential sources of conflict and future threats to peace and security, May 2012, Institute for Security Studieshttps://www.files.ethz.ch/isn/145411/Paper_233.pdf; Resolving African Boundary Disputes https://www.africaoilandpower.com/2018/03/20/resolving-boundarydisputes-in-africa/. (accessed 15 February, 2020).

${ }^{80} \mathrm{Ibid}$. Institute for Security Studies, note 2. 
of an OAU Boundaries Commission in $1981^{81}$ and Established the African Boundary Programme in 2007. ${ }^{82}$ In 2013 the AUBP published a valuable study, "Delimitation and Demarcation of Boundaries in Africa, General Issues and Case Studies" covering highly relevant topics including establishment of national and bi-national boundary commissions; case studies of boundary demarcations in Africa, including Nigeria's many boundaries; approaches to dealing with affected populations; and boundary management. ${ }^{83}$

\subsubsection{The Hazards of Boundary Adjustment}

A review of the literature on African boundary disputes and adjustment provides strong reason for care and caution by the parties as they work to establish a peaceful, properly administered boundary that facilitates the comprehensive cooperation and friendly relations to which they are committed by the 2018 Agreements. Such a review of this extensive store of knowledge by the new High-Level Joint Committee of Ethiopia and Eritrea should be a priority. The case studies of successful boundary adjustments and the analyses of unsuccessful ones all point to this: an enormous amount of good will, work, time and money are required to move from even the soundest boundary delimitation on paper to a workable and mutually accepted demarcation on the ground. There are no short cuts. ${ }^{84}$

\subsubsection{Problems Specific to the Eritrea-Ethiopia Boundary}

The boundary adjustment issue for Eritrea and Ethiopia poses particularly difficult facts and circumstances. First, the current boundary has been in place, apart from minor variations, as an international or internal boundary at least since the mid-1940s. It has been in place as an international boundary since 1992, except for the two years of the 1998 war. During this entire period, and even before, until 1998, there was relatively free movement of goods and people across the boundary. Adjustments to a boundary of such long-standing require careful study by the parties just to determine what disruptions may be expected from any change and how best to minimize them.

Second, there has never been a serious and detailed study of the Ethiopia-Eritrea boundary region which involved the two governments and the residents of these regions. Best practice for delimitation and demarcation is for residents of affected regions to be fully involved in at least the demarcation process in order to understand and minimize problems and prevent ongoing disruption and violence when the border is in place. The study of boundary regions and their residents should be conducted by a joint boundary commission, though each state will probably do their own study as well. ${ }^{85}$

\footnotetext{
${ }^{81}$ Ibid. note 19.

82 African Union (2009).

83 African Union Border Program (2014).

84 See generally, ibid.

${ }^{85}$ Ibid at Chapters 3, 8, 11.
} 
Third, work of the joint boundary commission must be both top down, reflecting each state's government's concerns, and bottom up, reflecting the affected local population's and leaders' concerns. Chief among the concerns will be whether the new boundary is to be a barrier or a bridge. Among the decisions to be made in view of national and local concerns are, e.g. where customs posts and crossing points will be established, what standards there will be for imports and exports and what documents are required for movement of people and goods.

Fourth, the Ethiopia-Eritrea boundary region includes a number of rivers. Some of these will reward joint management and development to allow both countries to benefit in a fair and environmentally sound manner.

Finally, boundary management is a never-ending issue for both parties. Even states with the most long-standing, friendly relations have recognized the need for permanent boundary commissions to deal with shared resources, emergencies, natural disasters, crime, etc. ${ }^{86}$

\subsubsection{The Bakassi Dispute as Cautionary Example}

Nigeria shares land and maritime boundaries with seven sovereign states and has made steady progress over many years in reaching agreement with them on delimitation, demarcation and management. The central concept permitting this success has been deep engagement between Nigeria and the neighboring states at national and local levels, focusing on the needs of local affected communities. Not all binational boundaries are fully delimited, demarcated and subject to full agreements on management and joint development of shared resources, but most are at some stage of friendly progress in this direction. ${ }^{87}$

An outstanding exception to this favorable experience is the boundary between Nigeria and Cameroon along the Bakassi Peninsula. This boundary was a subject of dispute long before independence of the two states. In 1994 Cameroon brought the dispute to the International Court of Justice (ICJ). In 2002 the ICJ issued a decision allocating most of the Peninsula to Cameroon while urging the states to ensure that the rights and interests of the local population were respected. Nigeria initially rejected the decision. The great majority of the Bakassi population had long considered themselves Nigerian and Nigeria had administered the territory. The UN Secretary General mediated between the two heads of state and secured an agreement to implement the decision. Initially this heads-of-state agreement was rejected by Nigeria's legislative body. The demarcation was done by a commission made up of delegates from each government and representatives of the U.N. Demarcation proceeded, including with some level of attention given to the affected local population but with strict implementation of the ICJ delimitation decision. The result has been constant disruption and extensive

\footnotetext{
86 See, e.g. International Boundary Commission $\quad$ (U.S./Canada) http://www.internationalboundarycommission.org/; International Joint Commission (U.S./ Canada) https://www.ijc.org/en (accessed 22 January 2020); International Boundary and Water Commission, United States and Mexico, https://www.ibwc.gov/home.html (accessed 22 January 2020).

${ }^{87}$ Asiwaju, A.I. (2013).
} 
displacement of the local population, most of whom are Nigerian. Many have fled to Nigerian territory but without adequate means of support or employment opportunities. Sporadic armed conflict and massive displacement continues until today, eighteen years after the ICJ decision. ${ }^{88}$

Some of the similarities between the Bakassi and the Ethiopia-Eritrea boundary cases include: first, one of the parties to the case, Cameron, welcomed the decision, while Nigeria raised concerns and objections at the beginning ${ }^{89}$. The second concerns that it was clear for both sides that the Court's judgement did not end the dispute between them ${ }^{90}$. Conversely, the major difference between the two cases regards while Cameroon and Nigeria continued, even if slowly, their engagement, Ethiopia and Eritrea opted for total non-engagement. At the end of the day, Nigeria and Cameron needed to enter into a series of negotiations that led to concluding a new agreement and establish a joint border Commission to try to resolve their respective concerns, including the rights of the indigenous populations there ${ }^{91}$. As each case of boundary dispute is unique, what is needed is to learn lessons from other cases and not duplicate them.

\subsubsection{The necessity of lesson learning and adjustments}

Section 4.3 above described the unique ethnic, linguistic and cultural characteristics of the longestablished communities in the border region. It also cited the opinions of experts strongly criticizing the Boundary Commission's Delimitation Decision based, inter alia on the basis of its disruptive effect on the affected local communities and therefore on relations between the two states. Ethiopia raised these issues with the Boundary Commission but Eritrea refused to consider any adjustment of the Delimitation Decision to address these serious issues. It is clear from the relevant literature and experience with other African boundaries that international law and practice now requires consideration of such concerns in boundary adjustments pursuant to the 2018 Agreements.

\section{Concluding Remarks}

Three remarks recap the article. First, Ethiopia and Eritrea should exploit the 2018 agreements to start afresh in their relations and co-existence as good neighbors. Secondly, if they focus on mutual benefit and joint development the rest can be sorted through time. And thirdly, a hard lesson must be learnt: any concerns and disagreements must be resolved only using peaceful and cooperative means and never by force. What is necessary is that (i) the two countries devote themselves to a transparent,

88 Ibid. pp.146-147; Egede (2018) 80-94; TRTWORLD, “The Lifelong consequences of a little-known Nigeria-Cameroon land dispute", 16 May, 2019, https://www.trtworld.com/magazine/the-lifelongconsequences-of-a-little-known-nigeria-cameroon-land-dispute-26701 (accessed 01 February, 2020). For an interesting comparison between Bakassi and Badme see Gibril (2003 ) 633-677.

${ }^{89}$ Ekaney (2018) 58.

${ }^{90}$ Ibid.

${ }^{91}$ Edege (2018) 80-99. 
institutionalized and participatory program to implement robust initiatives of the sort that are anticipated in the recent agreements; and (ii) the new relationship is founded upon treaty arrangements, international law and mutual trust.

Short bio of authors

Don Picard is a partner in Picard Kentz \& Rowe LLP in Washington D.C.. He participated as a member of Ethiopia's legal team in negotiating the Algiers Agreements and in proceedings before the boundary and claims commissions established pursuant to those agreements.

Zeray Yihdego is a Professor and Chair holder in Public International Law at the Aberdeen Law School, UK. He is a Co-director of the Aberdeen Centre for Constitutional and Public International Law.

\section{References}

"Africa's International Borders as Potential Sources of Conflict and Future Threats to Peace and Security,” (May 2012). Institute for Security Studies, No. 233.

"Agreement on Peace, Friendship and Comprehensive Cooperation Between the Federal Democratic Republic of Ethiopia and the State of Eritrea" (16 Sept 2018), available from http://www.shabait.com/news/local-news/27076-agreement-on-peace-friendship-andcomprehensive-cooperation-between-the-federal-democratic-republic-of-ethiopia-and-the-state-oferitrea.

“Eritrean Foreign Minister Views Ethiopia’s Position as a Declaration of War," (16 Dec 2003). Sudan Tribune.

"Ethiopia and Eritrea - UNMEE - Background," (2008) United Nations Mission in Ethiopia and Eritrea.

'Ethiopia-Eritrea: Peace Agreement 'Accepted' (2018) Africa Research Bulletin: Political, Social and Cultural Series, 55(6), 21889A-21891C.

"Interview with Recalled AU Ambassador Salih Omer" (21 Nov 2003) IRIN. Accessed from https://reliefweb.int/report/eritrea/eritrea-interview-recalled-au-ambassador-salih-omer.

"Joint Declaration of Peace and Friendship between Eritrea and Ethiopia," (2018) Shabait (9 July 2018). Available from http://www.shabait.com/news/local-news/26639-joint $\% 20$-declaration-ofpeace-and-friendship-between-eritrea-and-ethiopia.

"Protocol Additional to the Geneva Conventions of 12 August 1949, and relating to the Protection of Victims of International Armed Conflicts (Protocol I), 8 June 1977” (1977) available from https://www.un.org/en/genocideprevention/documents/atrocity-crimes/Doc.34 AP-I-EN.pdf. 
"Resolving African Boundary Disputes" (20 Mar 2018) Africa Oil and Power. https://www.africaoilandpower.com/2018/03/20/resolving-boundary-disputes-in-africa/.

"Resolving the Ethiopia-Eritrea Border: What Actually Needs to Be Done?" (2018) African Arguments. https://africanarguments.org/2018/06/18/resolving-ethiopia-eritrea-border-actuallyneeds-done/.

"Vienna Convention on the Law of Treaties" (1969) United Nations, Treaty Series, 1155: 331-53.

"Yearbook of the United Nations, 2006," Vol. 60. New York: United Nations Publications.

Abbink, Jon (2003) "Badme and the Ethio-Eritrean Border: The Challenge of Demarcation in the Post-War Period.” In: Africa: Rivista trimestrale di studi e documentazione dell'Istituto italiano per l'Africa e l'Oriente, 219-231. Instituto Italiano per l'Africa e l'Oriente.

Abbink, Jon (2009) "Law Against Reality? Contextualizing the Ethiopian-Eritrean Border Problem." In: The 1998-2000 War between Eritrea and Ethiopia, 141-58.

Abraham, Kinfe (2004) “Ethio-Eritrean History and the Ethio-Eritrean War.” Ethiopian International Institute for Peace and Development.

African Union (2009). Report of the Commission on the Implementation of the African Union Border Programme (AUBP), EX.CL/459(XIV) 2009

African Union (Jan 2009) "Report of the Commission of the Implementation of the African Union Border Programme (AUBP).” Executive Council, EX.CL/459 (XIV).

African Union Border Program (2014) "Delimitation and Demarcation of Boundaries in Africa, General Issues and Case Studies," $2^{\text {nd }}$ ed.

Agreement Between The Government Of The Federal Democratic Republic Of Ethiopia And The Government Of The State Of Eritrea, Algiers, Algeria, 12 December, 2000 at https://pcacases.com/web/sendAttach/786

Anebo, Lantera (2017) “The Fallacy of Virtual Demarcation as a Primary Scheme of International Land Boundary Setting: Why the Eritrea/Ethiopia Boundary Conflict Remains Unresolvable?" Willamette Journal of International Law and Dispute Resolution, 24 (2): 257-95.

Asiwaju, A.I. (2013) “The Factor of Affected Local Populations." In: Delimitation and Demarcation of Boundaries in Africa, 2nd ed., 136-52. Commission of the African Union, Department of Peace and Security.

Atinafu, Kidanu, and Endalcachew Bayeh (2015) "The Ethio-Eritrean Post-War Stalemate: An Assessment on the Causes and Prospects.” Humanities and Social Sciences, 3 (2): 96-101.

Aust, Anthony (2013) "Modern Treaty Law and Practice.” 3rd ed. Cambridge University Press.

Barry, Tom and Patrick Gilkes (11 Oct 2005) “The War Between Ethiopia and Eritrea.” Institute for Policy Studies. 
BBC News (2 Jan 2004) "Eritrea rejects new peace envoy," http://news.bbc.co.uk/2/hi/africa/3362301.stm.

Bereketeab, Redie (2019) "The Ethiopia-Eritrea Rapprochment: Peace and Stability in the Horn of Africa." Policy Dialogue 13. The Nordic Africa Institute.

Bereketeab, Redie. (2009) 'The Eritrea-Ethiopia Conflict and the Algiers Agreement: Eritrea's Road to Isolation." In: Eritrea's Regional Role and Foreign Policy: Past, Present and Future Perspective, 98-129. Chatham House and Brookings Institution Press.

Bezabih, Wuhibegezer Ferede (2014) "Fundamental Consequences of the Ethio-Eritrean War [19982000].” Journal of Conflictology, 5 (2).

Boundary Commission Statement (2006) REPORTS OF INTERNATIONAL ARBITRAL AWARDS 27 November 2006, VOLUME XXVI pp. 771-799

Clapham, Christopher (16 Oct 2003) “Notes on the Ethio-Eritrean Boundary Demarcation," available from www.aiga-forum.com/clapham0311.

Crawford, James (2019) “Brownlie’s Principles of Public International Law.” New York, NY: Oxford University Press.

Del Castillo, Graciana (2008) "Rebuilding War-Torn States: The Challenge of Post-Conflict Economic Reconstruction." UOP Oxford.

Desta, Melaku Geboye (2019) "Peace Agreements Between Ethiopia and Eritrea: Ending Two Decades of Hostilities - An Introductory Note," in Ethiopian Yearbook of International Law 2018, 261-268.

Egede, H (2018).'The ICJ Bakassi Decision: The rights of the indigenous communities and populations in the Bakassi Peninsula; in Egede, E \& Igiehon, M eds. The Bakassi Dispute and the International Court of Justice: Continuing Challenges. Taylor \& Francis. 80-99

Ekaney, ByNkwelle (20180 'The ICJ decision on the Cameroon- Nigeria Bakassi dispute and issues arising: A Cameroonian perspective' in Egede, E \& Igiehon, $\mathrm{M}$ eds. The Bakassi Dispute and the International Court of Justice: Continuing Challenges. Taylor \& Francis. 58-79

Eritrea asks international community to help avoid a "new war" with Ethiopia', AFP (9 January 2004).

Eritrea Ethiopia Claims Commission (28 April 2004) PARTIAL AWARD Central Front Eritrea's Claims 2, 4, 6, 7, 8 \& 22 https://pcacases.com/web/sendAttach/753

Eritrea Ethiopia Claims Commission Partial Award Economic Loss Throughout Ethiopia Ethiopia's Claim 7 (19 December 2005) https://pcacases.com/web/sendAttach/762

Eritrea-Ethiopia Boundary Commission. (13 April 2002) "Eritrea-Ethiopia Boundary Commission Decision Regarding Delimitation of the Border between The State of Eritrea and The Federal Democratic Republic of Ethiopia," available from https://legal.un.org/riaa/cases/vol XXV/83229.pdf. 
Eritrea-Ethiopia Claims Commission (19 Dec 2005) "Partial Award: Jus Ad Bellum - Ethiopia's Claims 1-8,” available from https://legal.un.org/riaa/cases/vol XXVI/457-469.pdf.

Eritrea-Ethiopia Claims Commission (2009) "Final Award: Ethiopia's Damages Claims between The Federal Democratic Republic of Ethiopia and The State of Eritrea."

Eritrea-Ethiopia Claims Commission, (28 April 2004) "Partial Award: Central Front - Ethiopia's Claim 2," available from https://legal.un.org/riaa/cases/vol XXVI/155-194.pdf.

Fixdal, Mona, ed (2012) “Ways Out of War: Peacemakers in the Middle East and Balkans." Palgrave MacMillan.

Geda, Alemayehu, and Befekadu Degefe (2005) "Conflict, Post-Conflict and Economic Performance in Ethiopia." In: Augustin Kwasi Fosu and Paul Collier, eds. Post-Conflict Economies in Africa, 12542. London: Palgrave Macmillan UK.

Gibril, Nejib (2003). "The Binding Dilemma: From Bakassi to Badme - Making States Comply with Territorial Decisions of International Judicial Bodies." American University International Law Review 19, no. 3: 633-67

Gibril, Nejib. (2003) "The Binding Dilemma: From Bakassi to Badme - Making States Comply with Territorial Decisions of International Judicial Bodies." American University International Law Review 19, no. 3: 633-677.

Gray, Christine (2006) “The Eritrea/Ethiopia Claims Commission Oversteps Its Boundaries: A Partial Award?” in The European Journal of International Law Vol. 17, 701-721.

Healy, Sally, and Martin Plaut (2007) "Ethiopia and Eritrea: Allergic to Persuasion," Chatham House, available from https://www.chathamhouse.org/sites/default/files/public/Research/Africa/bpethiopiaeritrea.pdf.

Ian Martin (2005) "Keeping the Peace: The United Nations Mission in Ethiopia and Eritrea," in Jacquin-Berdal, Dominique, and Martin Plaut, eds. Unfinished Business: Eritrea and Ethiopia at War. Lawrenceville, NJ: Red Sea Press.

International Boundary and Water Commission (U.S./ Mexico) https://www.ibwc.gov/home.html.

International Boundary Commission (U.S./Canada) http://www.internationalboundarycommission.org/en/

International Joint Commission (U.S./Canada) https://www.ijc.org/en

Iraq-Turkey: Treaty between United Kingdom and Iraq and Turkey regarding settlement of Frontier between Turkey and Iraq, together with Notes Exchanged, Angora, June 5, 1926. Great Britain, Treaty Series, No. 18 (1927), Cmd. 2912. Article 1.

Jacquin-Berdal, Dominique, and Martin Plaut, eds (2005) "Unfinished Business: Eritrea and Ethiopia at War.” Lawrenceville, NJ: Red Sea Press.

Jones, Stephen B (1945) "Boundary-Making: A Handbook for Statesmen, Treaty Editors, and Boundary Commissioners.” Johnson Reprint Corp. 
Khadiagala, Gilbert (1999) "Reflections on the Ethiopia-Eritrea Border Conflict." The Fletcher Forum of World Affairs, 23 (January): 39-56.

Maru, Mehari Taddele (2019) "Beyond Borders and Leaders: Toward Sustainable Peace for Ethiopia and Eritrea on Ethiopia/Eritrea," https://studies.aljazeera.net/en/reports/2019/07/bordersleaders-sustainable-peace-ethiopia-eritrea-190707092131678.html.

Meron, Theodor (1987) "The Geneva Conventions as Customary Law." The American Journal of International Law, 81(2), 348-370.

Mitchell, Andrew, M Sornarajah, M \& and Voon, Tania (2015). Good Faith and International Economic Law. Oxford, Oxford University Press.

Murphy, Sean D., Won Kidane, and Thomas R. Snider (2013) "Litigating War: Arbitration of Civil Injury by the Eritrea-Ethiopia Claims Commission.” Oxford; New York: Oxford University Press.

OAU High Level Delegation (1998) "Proposals for a Framework Agreement for a Peaceful Settlement of the Dispute Between Eritrea and Ethiopia", available from http://www.dehai.org/conflict/oau/oau-framework-11-98.htm.

Orakhelashvili, Alexander (2008) "Peremptory Norms in International Law." Oxford Monographs in International Law. Oxford; New York: Oxford University Press.

Orakhelashvili, Alexander (2008) "The Interaction between Human Rights and Humanitarian Law: Fragmentation, Conflict, Parallelism, or Convergence?” EJIL 19, 161-182.

Pankhurst, Richard (2001) "The Ethiopians: A History." The Peoples of Africa. Oxford; Malden, Mass: Blackwell Publishers.

Prendergast, John (2001) "U.S. Leadership in Resolving African Conflict: The Case of EthiopiaEritrea.” United States Institute of Peace. https://www.usip.org/publications/2001/09/usleadership-resolving-african-conflict-case-ethiopia-eritrea.

Reisman, W. Michael (1971) "Nullity and Revision; the Review and Enforcement of International Judgements and Awards."

Reisman, W. Michael (1971) Nullity and Revision; the Review and Enforcement of International Judgements and Awards. Yale University Press.

Simmons, Beth A. (1999) "Territorial Disputes and Their Resolution: The Case of Ecuador and Peru," in Peaceworks. United States Institute for Peace.

Snider, Thomas R., and Aishwarya Suresh Nair (2019) "Ten Years on: A Look at the Legacy of the Eritrea-Ethiopia Claims Commission,” in Ethiopia Yearbook of International Law 2018, 11-34.

Tekeste Negash, and Kjetil Tronvoll (2000) "Brothers at War: Making Sense of the Eritrean-Ethiopian War.” Eastern African Studies. Oxford: Athens: J. Currey; Ohio University Press.

The Federal Democratic Republic of Ethiopia (13 May 2002) "Request for Interpretation, Correction and Consultation," available from aigaforum.com/ethio1.pdf. 
The Federal Democratic Republic of Ethiopia (2 May 2003) "Comments to the Eritrea-Ethiopia Boundary Commission," available from http://www.geocities.ws/ethonlinepublication/Comments'ToEEBC.html.

The Federal Democratic Republic of Ethiopia (24 Jan 2003) "Comments Pursuant to the December 2000 Agreement, the Commission's Rules of Procedure, the Commission's Demarcation Directions and Instructions Provided at the Boundary Commission's Meeting on 6 and 7 November 2002."

Unah, Linus (16 May 2019) "The lifelong consequences of a little-known Nigeria-Cameroon land dispute" TRT World (16 May 2019) https://www.trtworld.com/magazine/the-lifelongconsequences-of-a-little-known-nigeria-cameroon-land-dispute-26701.

United Nations (18 Aug 2000) "Agreement on Cessation of Hostilities Between the Government of the Federal Democratic Republic of Ethiopia and the Government of the State of Eritrea", UN Treaty Series Volume 2138, I-37273.

United Nations (2002) “International Law Commission's Articles on State Responsibility: Introduction, Text and Commentaries.” Cambridge University Press.

United Nations (2002) Ethiopia/Eritrea: “Announcement of the EEBC Decision,” available from https://search.archives.un.org/uploads/r/united-nationsarchives/7/b/1/7b166a69540e94b69e564520b1d546496d47f669bd63207642159cf9b450b83d/S1095-0030-05-00003.pdf.

United Nations Iraq-Kuwait Boundary Demarcation Commission Press Release (18 March 1993), reprinted in Demarcation of the International Boundary Between the State of Kuwait and the Republic of Iraq by the United Nations 83 (Center for Research and Studies on Kuwait, n.d.).

United Nations, and Boutros Boutros-Ghali, eds (1996) "The United Nations and the Independence of Eritrea." The United Nations Blue Books Series, v. 12. New York: United Nations, Dept. of Public Information.

United Nations, General Assembly, 70 ${ }^{\text {th }}$ Session, A/CN.4/714 (12 Feb 2018), available from https://undocs.org/pdf?symbol=en/A/CN.4/714.

United Nations, General Assembly, Security Council, "Identical letters dated 12 December 2000 from the Permanent Representative of Algeria to the United Nations addressed to the Secretary-General and the President of the Security Council," A/55/686-S/2000/1183 (13 December 2000), available from undocs.org/S/2000/1183.

United Nations, Security Council, "Letter dated 16 July 1999 from the Permanent Representative of Eritrea to the United Nations Addressed to the President of the Security Council," S/1999/794 (16 July 1999) p. 5, available from undocs.org/en/S/1999/794.

United Nations, Security Council, "Letter dated 19 June 2000 from the Permanent Representative of Algeria to the United Nations addressed to the President of the Security Council," S/2000/601 (19 June 2000), available from undocs.org/en/S/2000/601. 
United Nations, Security Council, "Progress Report of the Secretary-General on Ethiopia and Eritrea," S/2003/1186 (19 Dec 2003), available from undocs.org/S/2003/1186.

United Nations, Security Council, "Progress Report of the Secretary-General on Ethiopia and Eritrea," S/2004/973/Add.1 (27 Dec 2004), available from undocs.org/S/2004/973/Add.1.

United Nations, Security Council, "Report of the Secretary General on Ethiopia and Eritrea," S/2007/645 (1 Nov 2007), available from undocs.org/S/2007/645.

United Nations, Security Council, "Resolution 1907," S/Res/1907 (23 Dec 2009), available from undocs.org/en/S/RES/1907

United Nations, Security Council, 5908 ${ }^{\text {th }}$ Meeting, S/PV.5908 (12 June 2008), available from https://undocs.org/en/S/PV.5908

Vienna Convention on the Law of Treaties, Vienna, 23 May 1969, UNTS vol. 1155, p. 331.

Weeramantry, J. Romesh (2006) "Eritrea Ethiopia claims Commission Awards," Hague Justice Journal, 45-47.

Woldemariam, Michael (2019) "The Eritrea-Ethiopia Thaw and Its Regional Impact". Current History, 118(808): 181-187. http:// currenthistory.com/Woldemariam-CH2019.pdf.

Yiallourides, Constantinos and Zeray Yihdego (2019) "Disputed Territories and the Law on the Use of Force: Lessons from the Eritrea-Ethiopia Case," in Ethiopian Yearbook of International Law 2018, $35-61$. 